РЫБКИНА Ольга Сергеевна - кандидат политических наук, доцент кафедры управления и маркетинга Нижегородского института управления - филиала Российской академии народного хозяйства и государственной службы при Президенте РФ (603950, Россия, г. Нижний Новгород, nр-кт Гагарина, 46; olya_07@mail.ru)

НГОМА ЛУХУОЛО Голди Жюниор - аспирант кафедры зарубежного регионоведения и локальной истории Нижегородского государственного университета им. Н.И. Лобачевского (603950, Россия, г. Нижний Новгород, ул. Ульянова, 2; juniordegoldy1@yahoo.fr)

\title{
ОСНОВНЫЕ ЭТАПЫ КОНГОЛЕЗСКО-АМЕРИКАНСКИХ ОТНОШЕНИЙ
}

Аннотация. В статье рассматривается проблема развития отношений между Республикой Конго и Соединенными Штатами Америки. Авторы выявляют их основные этапы и определяют особенности всех пяти этапов конголезско-американских отношений.

Ключевые слова: Республика Конго, США, международные отношения, история, этапы

B истории конголезско-американских отношений можно выделить несколько этапов. На первом этапе, который начался в 1960 г. с обретением Республикой Конго независимости (Год Африки!), в период президентства Ф. Юлу шло активное налаживание отношений с США, которые, в свою очередь, в рамках политики «новых рубежей» осуществляли активное проникновение в Африку [Гальперин 1984: 46; Нгома Лухуоло 2017б: 64]. Ф. Юлу даже посетил с официальным визитом Соединенные Штаты и встретился с 35-м президентом Д. Кеннеди [Нгома Лухуоло 2016: 266].

Второй этап начался 16 августа 1965 г. Именно тогда по инициативе президента РК А. Массамба-Деба под предлогом участия американского правительства в организации неудачного переворота сторонниками экс-президента Ф. Юлу было принято решение о разрыве дипломатических отношений с США. Исследователи отмечали, что этот шаг негативно сказался на экономике страны [Нганга-Мунгва 1983: 92]. Отметим также, что далеко не все африканские государства, заявившие о своем социалистическом выборе, пошли на разрыв дипломатических отношений с США.

Третий этап начался 1 июня 1977 г. в период президентства Ж. Йомби-Опанго. Именно тогда были восстановлены дипломатические отношения с США. Отчасти такой шаг можно объяснить тем, что тогдашний глава Народной Республики Конго считался в партии «правым» [Decraene 1979: 3]. Впрочем, по нашему мнению, этот шаг ничуть не противоречил ни ориентации на неприсоединение, ни даже ориентации на сотрудничество с капиталистическими странами, не затрагивающее идеологическую сферу. (Об этом в 1981 г. заявил Д. Сассу-Нгессо, подчеркнув, что НРК не откажется от осуждения политики администрации Р. Рейгана по тем вопросам, по которым она вступает в противоречие с интересами развивающихся стран [Зауде Зелеке 1991: 81].) Отчасти восстановление отношений с лидером западного мира можно также объяснить отходом от прокитайской маоистской линии во внешней политике, имевшей место при президенте А. Массамба-Деба. Отметим также, что до конца 1980-х гг. какого-либо реального сближения НРК с США не было.

В конце 1980-х гг. начался новый, четвертый этап конголезско-американских отношений. Связан он был с ослаблением советского влияния в Африке и, как следствие, снижением объема помощи НРК со стороны СССР. Нельзя также не упомянуть, что 40-й президент США Дж. Буш-старший и официальные 
представители Соединенных Штатов в конце 1980-х - начале 1990-х гг. неоднократно «выступали с настоятельными рекомендациями к лидерам африканских стран о необходимости соблюдения в их странах прав человека, внедрения демократических принципов в политическую и общественную жизнь» [Этитиэ 2004: 51]. Не отставала от них и британская дипломатия. Кроме того, президент Франции Ф. Миттеран в 1990 г. призвал африканских лидеров отказаться от авторитаризма и начать демократизацию режима [Этитиэ 2004: 51]. Итак, эти призывы при отсутствии социалистической альтернативы, равно как и очевидных успехов движения неприсоединения и интеграции по линии «юг - юг», показывали, что альтернативы реформам и сближению со странами Запада, в сущности, нет. То есть, уже упомянутые нами выше жесткие требования международных финансовых структур, которые выдвигали в качестве условия оказания содействия африканским странам осуществление ими демократических преобразований, были подкреплены позицией США, Великобритании и Франции [Этитиэ 2004: 55].

Относительно США имеет смысл утверждать, что что со времен президентства Ф. Юлу появились возможности для по-настоящему тесного сближения РК и этой сверхдержавы. Действительно, хотя американские отношения с Д. Сассу-Нгессо были относительно доброжелательными с 1988 г., когда именно Браззавиль служил местом для переговоров по мирным соглашениям между Анголой и Намибией, Соединенные Штаты вряд ли стали противостоять падению еще одного марксистско-ленинского режима в 1991 г. Логично, что в декабре 1991 г. один из лидеров Республики Конго А. Милонго совершил триумфальную поездку в США, где его принял в Белом доме 40-й президент Джордж Буш-старший. Последний пообещал поддержку конголезской демократии, а посол США в Браззавиле также приветствовал новое конголезское правительство [Menga 1993: 113]. То есть, на уровне риторики американские отношения с Конго значительно улучшились. Действительно, в те годы провозглашалось, что целью внешней политики США должна быть защита демократии по всему миру, так как Соединенные Штаты являются частью западной цивилизации и поэтому заинтересованы в распространении западных ценностей во всем мире. (Для сравнения: ранее пропаганда демократии не всегда была существенным элементом ее зарубежной политики.) Как следствие, американская администрация не могла не приветствовать появление ориентированного на демократические ценности бывшего просоветского государства.

Окончание «холодной войны» позволило США свободно продвигать демократию и права человека во всем мире. С начала 1990-х г. США сделали продвижение демократии основой своей внешней политики [Савченко, Устинкин, Агеева 2016: 96]. Однако все же следует признать, что основой «американской модели сотрудничества с Африкой [являлось] частное предпринимательство, координацию которого в странах континента осуществляет Корпоративный совет по Африке со штаб-квартирой в Вашингтоне, созданный в 1992 г.» [Зименков 2011: 6].

В таких реалиях для Республики Конго было естественным провозглашать верность демократически ценностям, отказ от социалистической ориентации и т.п. [Пахомова, Бугров, Фоменков 2015: 126]. В результате РК стала одним из государств Африки, получавшим американскую помощь за следование демократическим идеалам. Имеются сведения, согласно которым в 1990-2004 гг. РК наряду с Нигерией получила 300 млн долл. США [Fikreyesus 2012: 80-81]. Кроме того, была возможность активно привлекать американский капитал в конголезскую экономику.

Пятый этап в истории конголезско-американских отношений начался 
в 1997 г. после возращения к власти нынешнего главы государства Д. СассуНгессо. Последний, победив в гражданской войне в 1997 г., оказался во многом в международной изоляции (исключением являлась Франция). Влиятельные субъекты международных отношений - США, ФРГ, Великобритания и ряд других - высказывали неодобрение того, как произошел переход власти в РК [Lembe]. Можно, разумеется, упомянуть, что есть точка зрения, согласно которой в 1997 г. имел место своего рода компромисс между США и Францией. Последняя отказалась от попыток повлиять на ситуацию в Заире (ныне Демократическая Республика Конго), а США не стали вмешиваться в ситуацию в Браззавиле.

Так или иначе, но для улучшения экономического положения в РК требовалась не только поддержка со стороны Франции. Однако представители ЕС и США настойчиво требовали от вернувшегося к власти Д. Сассу-Нгессо соблюдения демократических норм и процедур [Makouta-Mboukou 1999: 159]. Эти обстоятельства способствовали установлению в РК так называемой имитационной демократии.

Отношения с США также в целом были восстановлены. Не случайно в 2006 г. в Браззавиле было открыто новое посольство США в РК. Сам Д. СассуНгессо стремился всячески демонстрировать американским партнерам, что он готов адаптироваться к требованиям окружающего мира, в котором де-факто доминируют США [Baluev et al. 2017: 28]. Кроме того, он выражал стремление привлечь новых инвесторов из США, а также подписать экономические соглашения и протоколы в целях дальнейшего укрепления экономических связей между двумя странами, в т.ч. в области добычи углеводородного сырья, где традиционно доминировал французский капитал. Упрочили свое влияние в РК также такие американские гиганты нефтяной индустрии, как Chevron и Texaco [Lembe]. Кроме того, в РК появилось представительство американского гиганта агробизнеса Seabord Corporation, расположенное в главном городе Южного Конго Долисье. Присутствие этих фирм - символов американского могущества придало новый импульс двусторонним экономическим и политическим отношениям между Республикой Конго и ведущей мировой державой.

В последние годы отношения между режимом Д. Сассу-Нгессо и США усложнились. Прежде всего, укажем, что к 2016 г. у Д. Сассу-Нгессо уже давно были натянутые отношения с корпорацией «Эксонмобил» и его главой Рексом Тиллерсоном, ставшим в 2017 г. госсекретарем США. Связано это с тем, что глава РК не предоставлял корпорации желаемых ей преференций при добыче нефти в Конго. Д. Сассу-Нгессо, как и другие авторитарные африканские лидеры, стремится к иностранному покрытию внутренних проблем. В этом ключе главная задача - добиться того, чтобы США не препятствовали президентству Д. Сассу-Нгессо [Carter], несмотря на неоднозначность его прихода к власти в 2015 г., и последующему подавлению протестов в департаменте Пул на юге страны [Нгома Лухуоло 2017а]. Судя по всему, надежды на лояльность со стороны нынешнего президента США Д. Трампа в РК связывают с отсутствием у последнего интереса к проблемам прав человека и присущим ему же прагматизмом во внешнеполитической сфере.

\section{Список литературы}

Гальперин М.С. 1984. Реакционная сущность стратегии американского империализма в борьбе против национально-освободительного движения: дис. ... к.филос.н. Л. 186 с. 
Зауде Зелеке. 1991. Внешняя политика стран Африки в 1970-1980 г2. (на примере Анголы, Эфиопии, Конго и Мозамбика): дис. ... к.и.н. М. 148 с.

Зименков Р.И. 2011. США - Африка: Современные торговые отношения. Вестник Академии. № 3. С. 5-9.

Нганга-Мунгва А. 1983. Внешняя политика Народной Республики Конго после Августовской революции 1963 г.: дис. ... К.и.н. М. 142 с.

Нгома Лухуоло Г.Ж. 2016. Особенности внешней политики республики Конго в период президентства Ф. Юлу. - Гармонизация межнациональных отношений в условиях глобального общества: материалы международной молодежной научной конференции (отв. за вып. И.А. Зверева). Княгинино: НГИЭУ. С. 265-267.

Нгома Лухуоло Г.Ж. 2017а. К вопросу о политическом конфликте в департаменте Пул в Республике Конго. - Молодой ученый. № 14(148). С. 577-579.

Нгома Лухуоло Г.Ж. 2017б. Контрреволюционное содержание за революционной риторикой: К вопросу об американском проникновении в Африку во второй половине ХХ века. - Русская революция и современный мир: материалы всероссийской научной конференции с международным участием. В 2 ч. Н. Новгород: ННГМА. С. 61-67.

Пахомова Е.А., Бугров Р.В., Фоменков А.А. 2015. К вопросу о различиях в трактовке этической концепции либерализма. - Глобальный научный потенциал. № 6(51). С. 124-127.

Савченко И.А., Устинкин С.В., Агеева Н.А. 2016. Экспансия капитализма и культурное насилие в веберианских интерпретациях. - Власть. Т. 24. № 11. С. 94-100.

Этитиэ Ж. 2004. Кризис однопартийного режима и становление многопартийной системы в Республике Конго: дис. ... к.полит.н. М. 152 с.

Baluev D., Kazakov M., Rykhtik M., Ulmaeva L., Ustinkin S. 2017. Human Security Concept as an Analytical Framework for the Study of Asymmetric Conflict. - Espacios. Vol. 38. No. 44. C. 28-38.

Carter B.L. Congo President's Embarrassing Attempt to Ingratiate Himself to Donald Trump. URL: http://africasacountry.com/2017/01/congo-president-denissassou-nguessos-embarrassing-attempt-to-ingratiate-himself-to-donald-trump/ (accessed 02.08.2017). P. 3.

Decraene P. 1979. Coup d'État légal: Brazzaville. - Le Monde (France). 10 février.

Fikreyesus D. 2012. Oil and U.S. Foreign Policy towards Africa: Ph.D. dissertation, Georgia State University. Atlanta. 245 p.

Lembe S. La politique étrangère du Congo-Brazzaville(1997-2007): jeux et enjeux d'une realpolitik (Télécharger le fichier original). URL: https://www.memoireonline. com/08/11/4716/m_La-politique-etrangere-du-Congo-Brazzaville1997-2007--jeuxet-enjeux-dune-realpolitik0.html (accessed 30.17.2018).

Makouta-Mboukou J.-P. 1999. La destruction de Brazzaville ou la démocratie guillotine. Paris: L'Harmattan. $181 \mathrm{p}$.

Menga S.G. 1993. Congo: La transition escamotee. Paris: L'Harmattan. 217 p. 
RYBKINA Olga Sergeevna, Cand.Sci. (Pol.Sci.), Associate Professor of the Chair of Management and Marketing, Nizhny Novgorod Institute of Management - the branch of Russian Presidential Academy of National Economy and Public Administration (46 Gagarina Ave, Nizhny Novgorod, Russia, 603950; olya_07@mail.ru)

NGOMA LUKHUOLO Goldi Junior, postgraduate student at the Chair of Foreign Regional Studies and Local History, Lobachevsky State University of Nizhny Novgorod (2 Ul'yanova St, Nizhny Novgorod, Russia, 603950; juniordegoldy1@ yahoo.fr)

\section{THE MAIN STAGES OF THE CONGOLESE-AMERICAN RELATIONS}

Abstract. The article deals with the problem of the development of relations between the Republic of Congo and the United States of America. The authors reveal their main stages, and determine the features of all five stages of the CongoleseAmerican relations.

Keywords: Republic of Congo, USA, international relations, history, stages

МИРОНОВ Дмитрий Геннадьевич - кандидат философских наук, доцент Московского государственного университета им. М.В. Ломоносова. (119991, Россия, г. Москва, Ломоносовский пр-кт, 27, кopn.4;d-21312556@yandex.ru)

\section{НА ПУТИ К ВЛАСТИ}

Аннотация. Данная статья является рецензией на работу Ю.А. Васильева «Юрий Андропов. На пути к власти».

Ключевые слова: Ю.В. Андропов, Карело-Финская ССР, Великая Отечественная война, разведывательная деятельность, подпольная работа, партизанское движение, поздний сталинизм, партийная система, «ленинградское дело»

И нтерес к новой книге об Ю.В. Андропове [Васильев 2018] связан с участием ее в презентации в БиблиоГлобусе, организованной Российским философским обществом. Имя исторического деятеля советской эпохи было мне известно с детских лет, поскольку отец окончил Высшую командную школу КГБ СССР в составе известного «андроповского выпуска» и многие годы своей жизни отдал работе в спецслужбах. Запомнилось, как еще в школьные годы я прочитал статью Ю.В. Андропова с ярким названием «Мы защитим тебя, Карелия родная!» в сборнике красного цвета [Андропов 1983].

Как отмечает автор издания, личность и биография Ю.В. Андропова как человека и политика до сих пор окутаны множеством загадок и домыслов, являются объектом мифотворчества. Об этом свидетельствует значительная историография, в которой высказываются различные (нередко противоположные) точки зрения [Команда Андропова 2005; Медведев 2012; Минутко 2004; Млечин 2008; Семанов 2014; Синицин 2015; Чертопруд 2006; Шлейкин 2014]. Однако тайны начала пути к власти будущего председателя КГБ СССР и Генерального секретаря ЦК КПСС практически не изучены. Начало пути к власти Андропова проходило в тяжелые годы. Не раз его политическая карьера оказывалась под угрозой. И не только карьера, но и само существование.

Следует обратить внимание на глубокое методологическое основание иссле- 